\title{
MIR155 wt Allele
}

National Cancer Institute

\section{Source}

National Cancer Institute. MIR155 wt Allele. NCI Thesaurus. Code C82110.

Human MIR155 wild-type allele is located in the vicinity of chromosome 21 and is 64 bases in length. This allele, which encodes MIR155 pre-miRNA, plays a role in the regulation of gene expression. Alteration in the expression of this gene is associated with the development of cancers of the breast and pancreas as well as acute lymphoblastic leukemia, diffuse large B-cell lymphoma, myeloproliferative disorder and hypertension. 